\title{
Peliosanthes arunachalensis (Asparagaceae), a new species from north-eastern India
}

\author{
D. K. Roy ${ }^{1, *}$, A. A. Mao ${ }^{1}$, L. V. Averyanov ${ }^{2}$ \\ ${ }^{1}$ Botanical Survey of India, Eastern Regional Centre, Lower New Colony, Laitumkhrah, Shillong - 793 003, Meghalaya, India. \\ E-mail:dilipbsierc@gmail.com \\ ${ }^{2}$ Komarov Botanical Institute, Russian Academy of Science, St.-Petersburg. Prof. Popov Str. 2, Russia, RU-197376 \\ E-mail:av_leonid@mail.ru; av_leonid@yahoo.com \\ *Corresponding author
}

Key words: Arunachal Pradesh, India, new species, Asparagaceae, Peliosanthes arunachalensis, Peliosanthes sinica.

Summary. Peliosanthes arunachalensis (Asparagaceae), a new species from the state of Arunachal Pradesh, northeastern India, is described and illustrated. It differs from similar congener, P. sinica, in having elongated scape, to 14 $\mathrm{cm}$ long, 7-10-flowered raceme shorter than scape, 2-3 cm long, bract equal or shorter than the flower, light grayish flowers, comparatively longer perianth segments, $6.5-7.5 \mathrm{~mm}$ long, with incurved margins, and superior ovary.

\section{Peliosanthes arunachalensis (Asparagaceae) - новый вид из Северо-Восточной Индии}

\author{
Д. К. Рой ${ }^{1}$, А. А. Мао ${ }^{1}$ Л. В. Аверьянов² \\ ${ }^{1}$ Ботаническая Служба Индии, Восточный Региональный Центр, Ловер Нью Колони, Лайтумкрах, \\ Шиллонг, 793 003, Мегхалая, Индия \\ ${ }^{2}$ Ботанический институт им. В. Л. Комарова РАН, ул. Проф. Попова, 2, Санкт-Петербург, 197376, Россия
}

Ключевые слова: Аруначал-Прадеш, Индия, новый вид, Asparagaceae, Peliosanthes arunachalensis, Peliosanthes sinica.

Аннотация. Peliosanthes arunachalensis (Asparagaceae), найденный в штате Аруначал-Прадеш на северо-востоке Индии, описывается в качестве вида, нового для науки. Приводятся аналитические иллюстрации нового таксона. Описываемое растение отличается от близкородственного P. sinica длинной ножкой соцветия (до 14 см дл.), 7-10-цветковой кистью 2-3 см дл. (которая отчетливо короче ножки соцветия), прицветниками (которые по длине равны или короче цветков), светло-сероватыми цветками, относительно длинными, 6,5-7,5 мм дл., долями околоцветника с краями, отчетливо загнутыми внутрь, и верхней завязью.

\section{Introduction}

The genus Peliosanthes Andrews belonging to the family Asparagaceae (APG, 2016) comprises about 32 species (Govaerts, 2017). It spreads mainly in south and south-east of continental Asia, including
Nepal, Bhutan, India, Myanmar, China, Cambodia, Laos, Vietnam, Thailand, Indochina and Malaysia (Averyanov, Tanaka, 2012; Averyanov et al., 2015; Averyanov et al., 2016). But numerical diversity in the genus Peliosanthes is ambiguous in India. 
While working on the genus Peliosanthes in north-eastern India, the authors encountered some interesting herbarium specimens (G. K. Deka s.n., 14 Nov. 1951, ASSAM 38205, 37430; R. S. Rao 17800, 18 Nov. 1958, ASSAM 19488, 19489). These specimens were marked as Peliosanthes violacea Wall. var. minor Baker, a synonym of $P$. griffithii Baker (Govaerts, 2017), from which they differ significantly, but morphologically similar to $P$. sinica $\mathrm{F}$. T. Wang \& T. Tang in stoloniferous habit. The flowers were dissected, and detailed morphological study was carried out based on the herbarium specimens and in the fields described in label data. Later on consultation of the literature (Baker, 1879; Hooker, 1894; Tanaka, 1999, 2004; Chen, Tamura, 2000; Averyanov, 2011; Averyanov, Tanaka, 2012, 2013; Tanaka et al., 2013; Averyanov et al., 2014, 2015, 2016), it became apparent that the specimens studied were morphologically different from all other known taxa of the genus, which warrant its description as a new species. Table 1 demonstrates the morphological differences between the novelty and the allied species, $P$. sinica.

\section{Taxonomic treatment}

Peliosanthes arunachalensis D. K. Roy, A. A. Mao \& Aver., sp. nov. (Figs. 1, 2).

Differs from allied species, Peliosanthes sinica in broadly elliptic leaf blade (vs. oblong to elliptic), elongated scape, to $14 \mathrm{~cm}$ long (vs. to $3.5 \mathrm{~cm}$ ), raceme shorter than scape, 2-3 cm long, 7-10-flowered (vs. longer than scape, $4.5-5 \mathrm{~cm}$, usually more than 10-flowered), light grayish flowers (vs. greenish purple), comparatively longer perianth segments, 6.5-7.5 mm long, with incurved margins (vs. 3.0$4.0 \mathrm{~mm}$ long, strongly revolute), superior ovary (vs. half-inferior).

Type: INDIA, Arunachal Pradesh: Aka Hills, Bomputa Camp, 9000 ft, 14. 11. 1951, G. K. Deka s.n. (holotype, ASSAM; isotype, ASSAM). Paratype: INDIA, Arunachal Pradesh: Siang F. D., Minguing to Take-Pokong, 1160-1740 m, 18. 11. 1958, R. S. Rao 17800 (ASSAM).

Description. Stoloniferous, terrestrial herbs; stolons with internodes to $20-25 \mathrm{~cm}$ long, $0.5 \mathrm{~cm}$ in diam., covered with remnants of whitish scarious scales on nodes. Cataphylls lanceolate, 5-10 $\times$ $0.7-1.0 \mathrm{~cm}$, papyraceous, later becoming partially disintegrated. Leaves 2, petiolate, suberect; petiole rigid, almost straight, terete, $13-20 \mathrm{~cm}$ long; leaf blade broadly elliptic, $16.5-21.5 \times 5.5-8.5$ $\mathrm{cm}$, acuminate to shortly attenuate, entire along margins, glabrous, glossy; longitudinal veins many, prominent; secondary veinlets conspicuous, spaced, sub-perpendicular to main veins. Scape axillary, bearing 1-2 sterile bracts, stout, elongated, longer than raceme, $12-14 \mathrm{~cm}$ long, ca. $2 \mathrm{~mm}$ in diam.; sterile bracts $1.2-2.0 \times 0.3-0.5 \mathrm{~cm}$, acuminate, margins membranous. Raceme 2-3 cm long, 7-10-flowered; rachis longitudinally finely ridged. Floral bracts 2 , scarious; bract located below flower, lanceolate, 0.8 $1.0 \mathrm{~cm}$ long, $1.5-2.0 \mathrm{~mm}$ wide, distally acuminate to subulate, concave, equal or shorter than the flower;
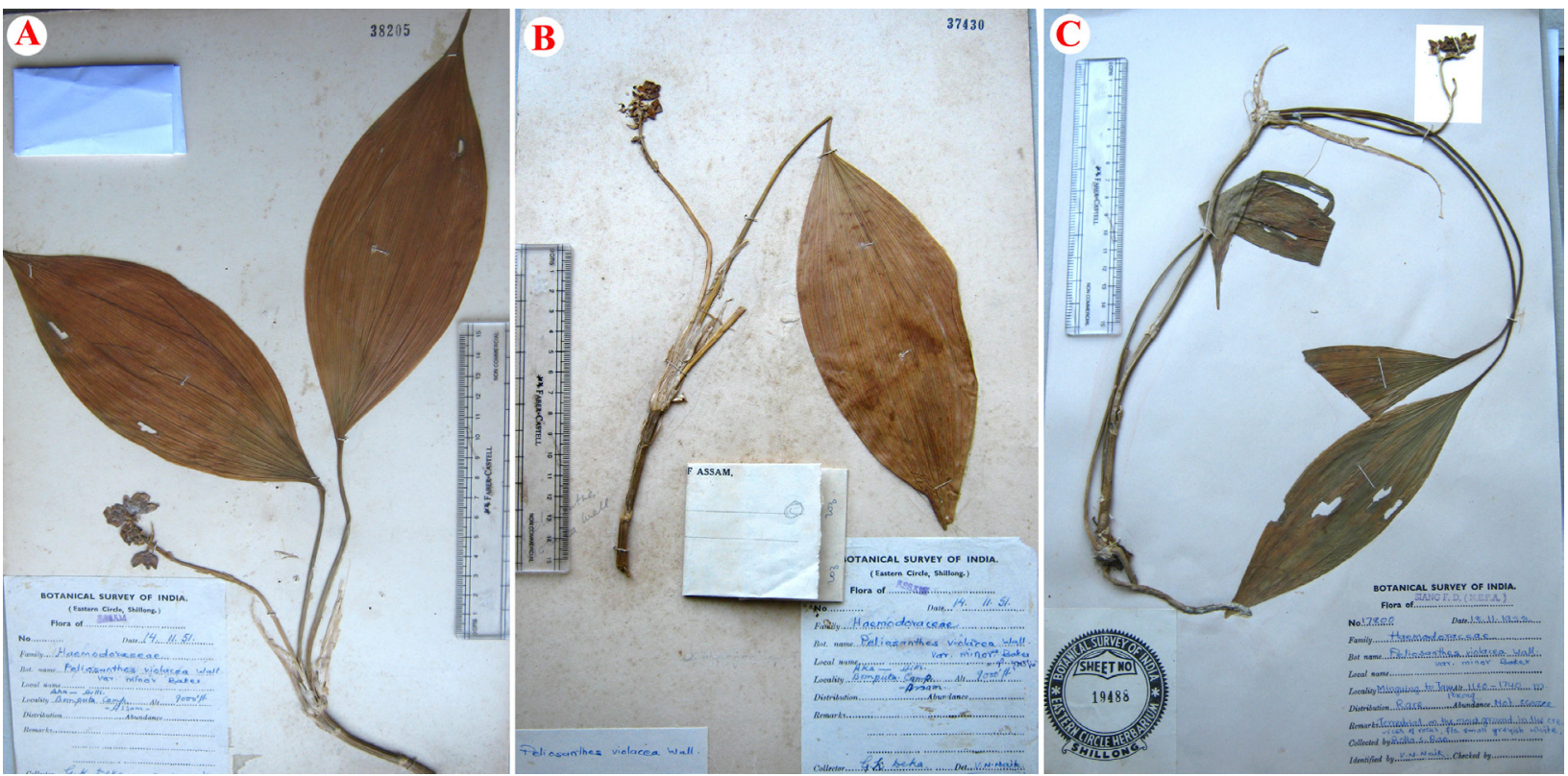

Fig. 1. Peliosanthes arunachalensis. A. Holotype (G. K. Deka s.n., ASSAM!, Acc. No. 38205). B. Isotype (G. K. Deka s.n., ASSAM!, Acc. No. 37430). C. Paratype (R. S. Rao 17800, ASSAM!, Acc. No. 19488). 


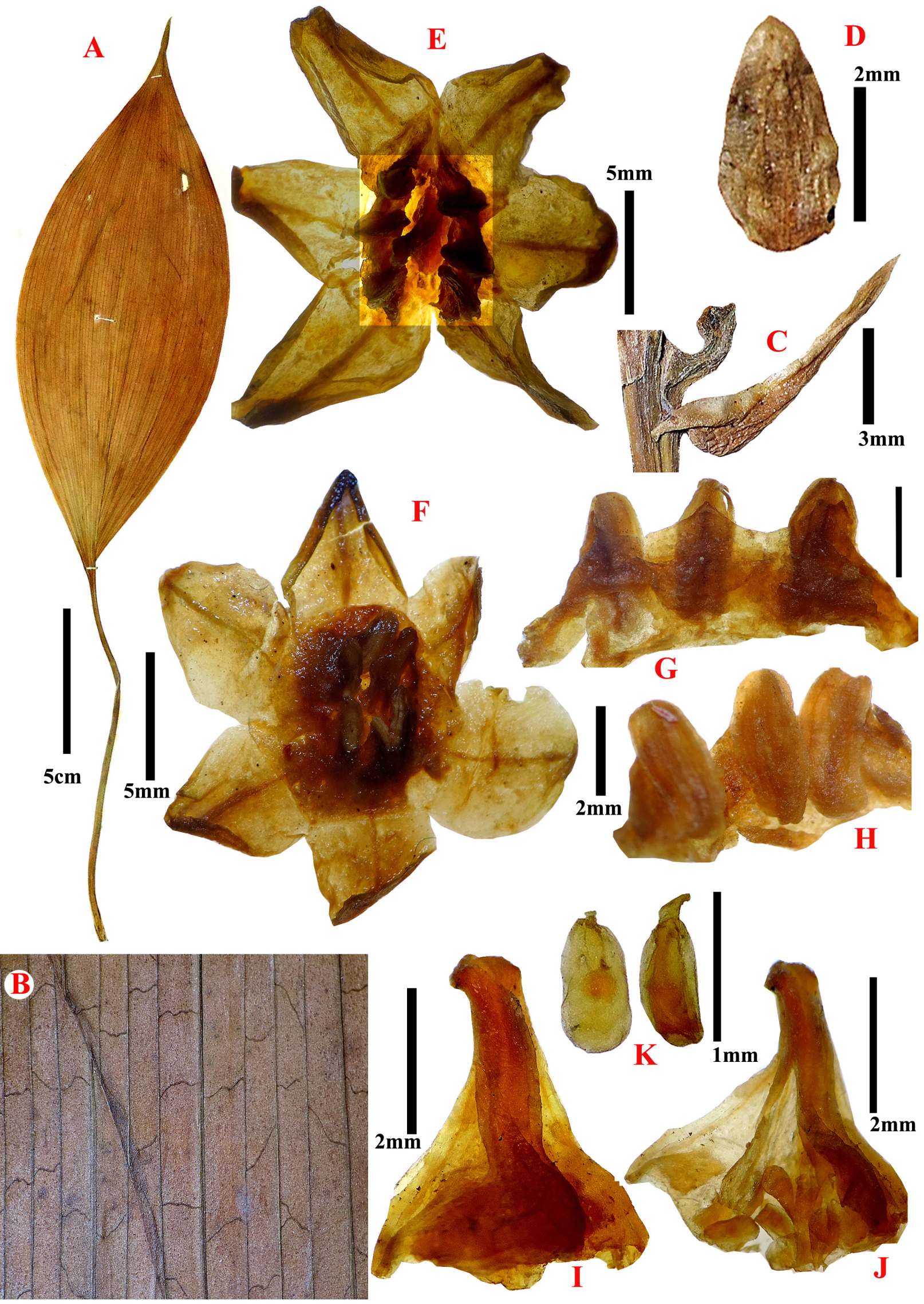

Fig. 2. Peliosanthes arunachalensis. A - Leaf. B - Leaf blade, surface bellow. C - Bract with pedicel. D - Bracteole. $\mathrm{E}$-Flower, frontal view showing the ovary. F-Flower, frontal view showing the corona. $\mathrm{G}$ - Portion of corona, dorsal view. $\mathrm{H}$ - Portion of corona, ventral view showing anthers. I - Intact pistil. J - Pistil with splitted ovary showing the ovules. K - Ovules. [Adopted from G. K. Deka s.n., ASSAM!, Acc. No. 38205]. 
bracteole lateral to flower, broadly ovate-triangular, $2.5-3.0 \times 1.5-2.0 \mathrm{~mm}$. Flower solitary in bracteal axil, pedicellate, broadly open, $1.2-1.5 \mathrm{~cm}$ across, nodding or slightly upward, light grayish; pedicel terete, longitudinally finely ribbed, $4-5 \mathrm{~mm}$ long, upturned or sub-horizontal. Perianth tube broadly obconical, 2-3 mm long; segments 6 , similar, ovate to ovate-triangular, obtuse, $6.5-7.5 \mathrm{~mm}$ long, 4-4.5 mm wide, spreading, slightly incurved at margins. Corona broadly conic, its base scarcely demarcated from tepals, $4.0-4.5 \mathrm{~mm}$ across, about $3 \mathrm{~mm}$ high, distinctly hexagonal. Anthers 6, sessile, introrse,

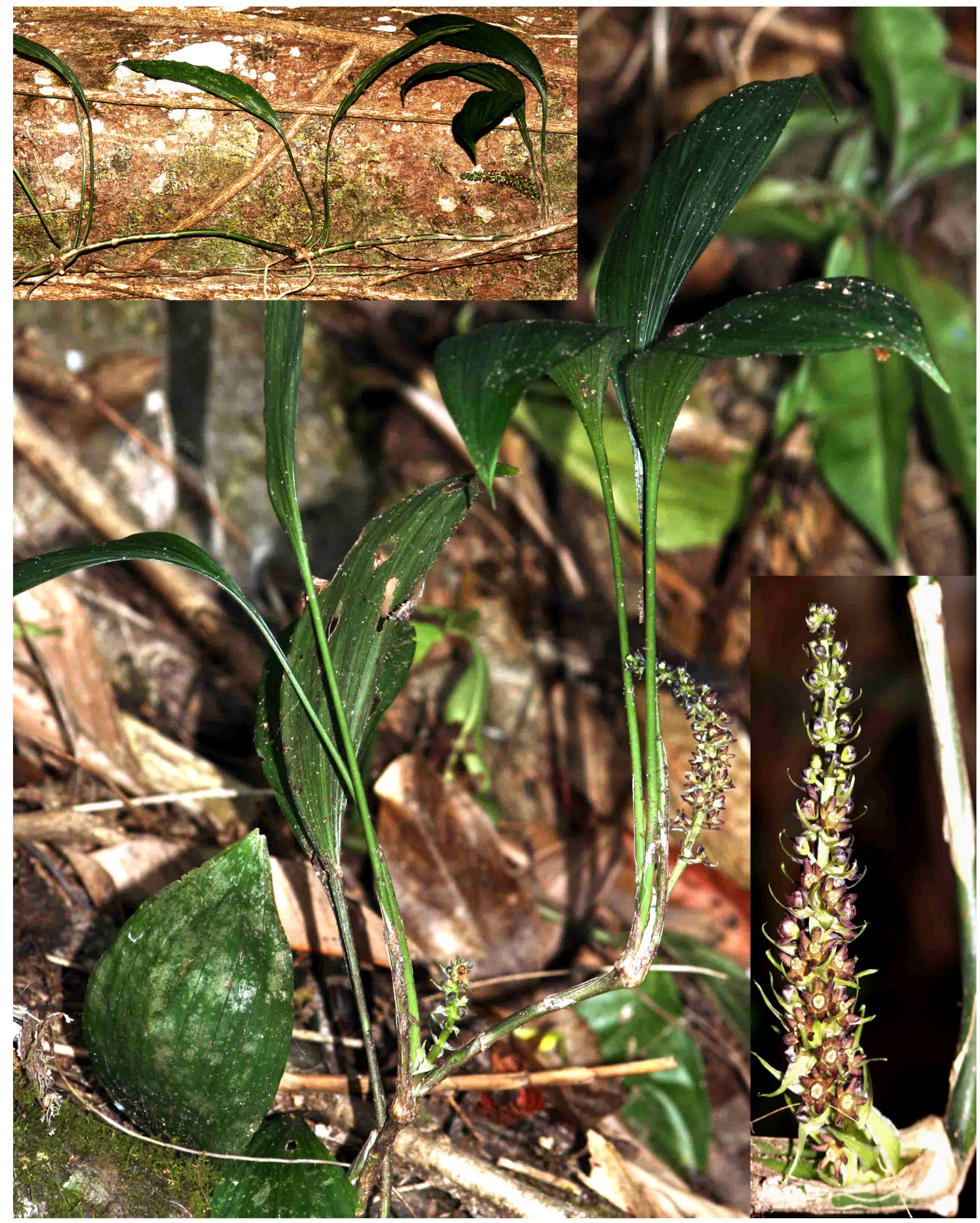

Fig. 3. Peliosanthes sinica. Photo by L. Averyanov. 
inserted at distal edges of corona, broadly ovoid, $3.0-3.5 \mathrm{~mm}$ long and 1.0-1.5 wide, light yellowish. Ovary superior, conical, $3.0-3.5 \mathrm{~mm}$ in diam., 3-loculed, each chamber containing 4 ovules on basal placenta; ovules oblong, $1 \mathrm{~mm}$ long, $0.5 \mathrm{~mm}$ wide; style broadly conical, 3 -angular, ca. $3 \mathrm{~mm}$ long; stigma 3-partite.

Flowering. November.

Etymology. The new species is named after the area of its origin (the state of Arunachal Pradesh, north-eastern India).

Habitat. Moist ground in the rock crevices.

Distribution. New species is still known only by herbarium specimens originated from Aka Hills and Siang F. D. of the state of Arunachal Pradesh, India.

Notes. Comparison of morphology between the known species of Peliosanthes indicates that $P$. arunachalensis is superficially similar to
P. sinica (Fig. 3) in stoloniferous habit with long petiole and many prominent, longitudinal veins on leaf blade. But $P$. arunachalensis is clearly differs from it in broadly elliptic leaf blade (vs. oblong to elliptic), elongated scape, to $14 \mathrm{~cm}$ long (vs. to $3.5 \mathrm{~cm}$ ), raceme shorter than scape, $2-3 \mathrm{~cm}$ long, 7-10-flowered (vs. longer than scape, $4.5-5 \mathrm{~cm}$, usually more than 10-flowered), light grayish flowers (vs. greenish purple), comparatively longer perianth segments, $6.5-7.5 \mathrm{~mm}$ long, ovate to ovatetriangular, with incurved margins (vs. 3.0-4.0 mm long, elliptic-lanceolate, strongly revolute), superior ovary (vs. half-inferior), see Table 1.

\section{Acknowledgements}

Authors are grateful to Dr. P. Singh, Director, Botanical Survey of India (BSI), Kolkata for facilities and encouragement.

Table 1

Comparison of morphological characters between Peliosanthes arunachalensis and P. sinica.

\begin{tabular}{|l|c|c|}
\hline \multicolumn{1}{|c|}{ Characters } & Peliosanthes arunachalensis & Peliosanthes sinica \\
\hline Leaf blade & Broadly elliptic, $16.5-21.5 \times 5.5-8.5 \mathrm{~cm}$ & Oblong to elliptic, $11-17 \times 3-6 \mathrm{~cm}$ \\
\hline Scape & $12-14 \mathrm{~cm}$ long & $3.0-3.5 \mathrm{~cm}$ long \\
\hline Raceme & $\begin{array}{c}\text { Shorter than scape, } 2-3 \mathrm{~cm} \text { long, } \\
7-10 \text {-flowered }\end{array}$ & $\begin{array}{c}\text { Longer than scape, } 4.5-7.0 \mathrm{~cm} \text { long, } \\
\text { usually more than } 10 \text {-flowered }\end{array}$ \\
\hline Bract & Equal or shorter than the flower & Longer than flower \\
\hline Flowers & Nodding or slightly upward, light grayish & Upward, greenish purple \\
\hline $\begin{array}{l}\text { Perianth } \\
\text { segments }\end{array}$ & $\begin{array}{c}\text { Ovate to ovate-triangular, } 6.5-7.5 \mathrm{~mm} \text { long, } \\
\text { slightly incurved at margins }\end{array}$ & $\begin{array}{c}\text { Elliptic-lanceolate, } 3.0-4.0 \mathrm{~mm} \text { long, } \\
\text { strongly revolute at margins }\end{array}$ \\
\hline Ovary & Superior & Half-inferior \\
\hline
\end{tabular}

\section{REFERENCES / ЛИTEPATУPA}

Angiosperm Phylogeny Group. 2016. An update of the Angiosperm Phylogeny Group classification for the orders and families of flowering plants: APG IV. Botanical Journal of the Linnean Society 181: 1-20.

Averyanov L. V. 2011. Peliosanthes yunnanensis and Trichosma yanshanensis - new additions to the flora of Vietnam. Taiwania 56: 143-148.

Averyanov L. V., Tanaka N. 2012. New species of Peliosanthes and Tupistra (Asparagaceae) from eastern Indochina. Taiwania 57: 153-167.

Averyanov L. V., Tanaka N. 2013. New species of Peliosanthes (Asparagaceae) from Vietnam. Turczaninowia 16, 2: 5-7.

Averyanov L. V., Tanaka N., Nguyen S. K. 2014. New species of Peliosanthes and Rohdea (Asparagaceae) from Eastern Indochina. Taiwania 59: 18-25.

Averyanov L. V., Tanaka N., Nguyen K. S., Nguyen H. T., Konstantinov E. L. 2015. New species of Ophiopogon Ker Gawl., Peliosanthes Andrews and Tupistra Ker Gawl. (Asparagaceae) in the flora of Laos and Vietnam. Adansonia sér. 3, 37 (1): 25-45.

Averyanov L. V., Tanaka N., Nguyen K. H., Truong B. V., Nghiem D. T., Nguyen T. H. 2016. New species of Ophiopogon, Peliosanthes and Tupistra (Asparagaceae s. 1.) in the flora of Vietnam. Nordic Journal of Botany 34: 23-37.

Baker J. G. 1879. Peliosanthes Andrews. Journal of the Linnean Society, Botany 17: 503-506.

Chen X.-Q., Tamura M. N. 2000. Peliosanthes Andrews. In: Z. Y. Wu, P. H. Raven and D. Y. Hong (eds.), Flora of China 24: 261-263. Science Press, Beijing, Missouri Botanical Garden Press, St. Louis. 
Govaerts R. 2017. World checklist of Asparagaceae. Facilitated by the Royal Botanic Gardens, Kew. Published on the internet; http:// apps.kew.org/wcsp/Retrieved 20.02.2017.

Hooker J. D. 1894. Liliaceae. In: Hooker J. D. (ed.), The Flora of British India. 6: 299-362. L. Reeve \& Co., London.

Tanaka N. 1999. Taxonomic notes on Peliosanthes (Convallariaceae) I. Acta Phytotax. Geobot. 50: 147-155.

Tanaka N. 2004. A new species of Peliosanthes (Convallariaceae) from Vietnam and China. Kew Bull. 59: 157159.

Tanaka N., Murata J., Wu S.-K. 2013. A new species of Peliosanthes (Asparagaceae) from Yunnan, China. Journal of Japanese Botany 88: 131-139. 